\title{
Does Mercenaria mercenaria encounter elevated food levels in seagrass beds? Results from a novel technique to collect suspended food resources
}

\author{
Michael L. Judge*, Loren D. Coen, Kenneth L. Heck, Jr \\ Marine Environmental Sciences Consortium, Dauphin Island Sea Lab, Dauphin Island, Alabama 36528, USA \\ and Department of Marine Sciences, University of South Alabama, Mobile, Alabama 36688, USA
}

\begin{abstract}
Previous estimates of suspended food resources have not incorporated the hydrodynamics of species-specific food entrainment. To assess food resources available to the siphonate bivalve Mercenaria mercenaria, we developed an in situ sampling protocol utilizing realistic incurrent siphon characteristics (e.g. diameter, sampling height and pumping rate) with simultaneous measurements of the current velocity profile. Microalgal food resources, as estimated by clam-biased chlorophyll a measurements, varied 10-fold over both temporal (hourly and seasonally) and spatial (centimeter and meter) scales in estuarine vegetated and adjacent unvegetated habitats. For the near bottom $(1 \mathrm{~cm}$ height) samples, chlorophyll a concentrations and variations were greater in a seagrass bed than those measured in the adjoining bare sand habitat. Samples collected at 5,15 , and $45 \mathrm{~cm}$ above the bottom did not exhibit any habitat-specific pattern. Up to $90 \%$ of the near-bottom microalgal count in the seagrass bed was pennate diatoms suggesting that much of the chlorophyll a is derived from the bed. Current speeds measured just above the bottom in the seagrass bed were considerably lower $(<1 \mathrm{~cm}$ $\mathrm{s}^{-1}$ ) than elsewhere. These results suggest a relatively concentrated, locally-generated near-bottom food resource for $M$. mercenaria within the vegetated habitat. Therefore, resource depletion (i.e. suspension feeders reducing the food level for others downstream) may not be relevant to hard clam populations at this site.
\end{abstract}

\section{INTRODUCTION}

Patterns in the distributions of oceanic phytoplankton have been demonstrated at many spatial and temporal scales (Parsons et al. 1977). To quantify these distributions, biological oceanographers typically collect water samples with minimal alteration of ambient currents (e.g. Nansen bottles), although many other designs have been used (e.g. Mitchell \& Fuhrman 1989). Nonetheless, because phytoplankton are generally small and near neutrally buoyant, individual cells tend to follow flow streamlines and collections will produce unbiased estimates of their instantaneous concentration.

This well-developed methodology, and its implicit assumption of a well-mixed (at the measurement scale)

\footnotetext{
- Present address: Department of Ecology and Evolution, State University of New York, Stony Brook, New York 11794. USA
}

phytoplanktonic source, has also been utilized to estimate the food levels available to benthic suspension feeders (Buss \& Jackson 1981, Fréchette et al. 1989, Irlandi \& Peterson 1991, Fegley et al. 1992). Unfortunately, estimating food levels available to these suspension feeders may require more than just measuring instantaneous chlorophyll concentrations. Active suspension feeders collect food particles in suspension from the water column above via a 'pump' (sensu Jørgensen et al. 1986). When pumping water, the paths of the small particles will conform to the streamlines because these particles have insufficient inertia to cross streamlines. Particles with larger masses (e.g. algal or sediment aggregations) may not follow the changes in water direction at the collection port faithfully and will be under-represented in collections. Thus, the traditional method of collecting water samples by matching the collection speed to the ambient current (i.e. isokinetic sampling) will likely produce higher estimates of the food level available than that 
actually experienced by the active suspension feeder (Vanoni 1946, Wildish \& Kristmanson 1984, Mushenheim et al. 1986). If the vertical distribution of food particles near the bottom is not uniform, then the situation may be further complicated because the active suspension feeder will draw food from several heights (Ertman \& Jumars 1988, Grizzle \& Lutz 1989, Judge et al. 1992)

To allow for the development of better predictors of infaunal bivalve growth rates, we sought to measure the food resources available to an individual hard clam and not instantaneous phytoplankton distributions. We have designed a sampling protocol that realistically simulates the active benthic suspension feeder Mercenaria mercenaria and have used this protocol to collect data on the variability in food resources. We chose to compare estuarine vegetated and unvegetated habitats inhabitated by $M$. mercenaria because seagrass blades are often fouled by chain-forming cpiphytic (pennate) diatoms and resuspension of sediments is common. By collecting from the perspective of a single individual and examining the food distribution pattcrns, we can ask if a clam is likely to experienre resource depletion (reduced food levels via competition for suspended particles). Because we designed our protocol for a particular suspension-feeding species, it may not be possible to generalize from our specific results to other (active or passive) suspension feeders, although the sampling protocol could be modified easily to evaluate other species. Nonetheless, this work is the first mechanistically realistic attempt to collect food resources for a specific benthic suspension feeder.

\section{MATERIALS AND METHODS}

The study location was a shallow subtidal site in Perdido Pass (Orange Beach, Alabama, USA: $30^{\circ} 17^{\prime} \mathrm{N}$,

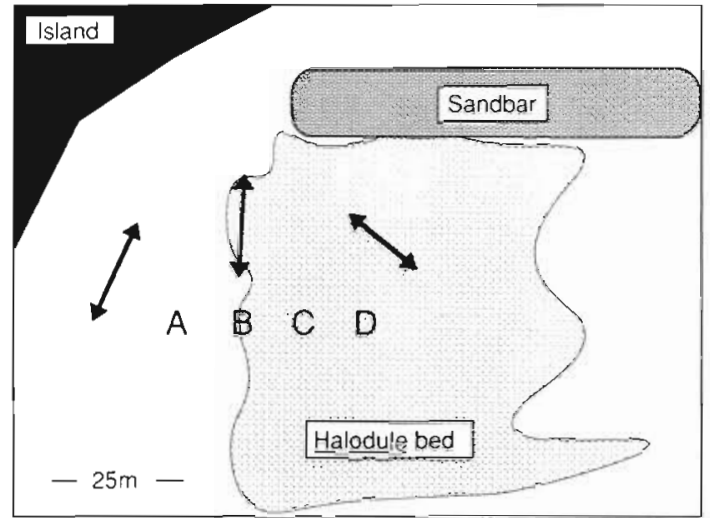

Fig. 1. Study site in Perdido Pass, Alabama (USA). Food resources and water currents were measured above the bare sand (A), edge of the Halodule wrightii seagrass bed (B), $12 \mathrm{~m}$ into the bed $(C)$ for the annual sampling, and the center of the bed (D). Currents, constrained by the adjacent sandbar, generally (but not always) flowed in the dirertion indicated by the arrows

$87^{\circ} 33^{\prime}$ W) with a Mercenaria mercenaria population in both sand and seagrass Halodule wrightii (Aschers) habitats (Fig. 1). M. mercenaria densities are generally low in the seagrass beds at Perdidio Pass [large adults (>10 cm length): 0.05 ind $\mathrm{m}^{-2}$ i juveniles $(<5 \mathrm{~cm}$ ): 0.5 ind. $\mathrm{m}^{-2}$ ]. Hard clams are rare in the adjacent unvegetated areas, but adults were occasionally found. Several growth experiments with $M$. mercenaria have been conducted recently near the study site (Coen \& Heck 1991, Wilson 1991, Judge et al. 1992, Coen, Heck \& Judge unpubl.). Seagrass and sediment characteristics are given in Table 1 . Water depth averaged $0.5 \mathrm{~m}$ in the sand and $0.35 \mathrm{~m}$ in the seagrass bed. Perdido Pass is essentially non-tidal (tidal range $<0.15 \mathrm{~m}$ ), with currents driven by the wind and modified by local bottom topography (Judge et al. 1992).

Table 1. Halodule wrightii and sediment characteristics at the 4 habitat types chosen in Perdido Pass, Alabama (USA). Maximum $H$. wrightii blade length (i.e. canopy height) and above ground biomass (dry) are given for both summer and winter. Sediment fractions were available only for Jamuary 1991 and were calculated according to the methods outlined in Coen \& Heck (1991).

Data are presented as mean and (SE)

\begin{tabular}{|c|c|c|c|c|c|c|}
\hline \multirow[t]{3}{*}{ Habitat } & \multicolumn{4}{|c|}{ H. wrightii } & \multicolumn{2}{|c|}{ Sediments } \\
\hline & \multicolumn{2}{|c|}{ Jul 1991} & \multicolumn{2}{|c|}{ Jan 1991} & & \\
\hline & $\begin{array}{c}\text { Blade } \\
\max .(\mathrm{mm})\end{array}$ & $\begin{array}{c}\text { Biomass } \\
\left(\mathrm{g} 0.01 \mathrm{~m}^{-2}\right)\end{array}$ & $\begin{array}{c}\text { Blade } \\
\text { max. (mm) }\end{array}$ & $\begin{array}{c}\text { Biomass } \\
\left(\mathrm{g} 0.01 \mathrm{~m}^{-2}\right)\end{array}$ & $\begin{array}{l}\% \text { Mud } \\
(<62 \mu \mathrm{m})\end{array}$ & $\begin{array}{c}\% \text { Organic } \\
\text { matter }\end{array}$ \\
\hline Bare sand & - & - & - & - & $\begin{array}{c}2.42 \\
(0.36)\end{array}$ & $\begin{array}{c}0.30 \\
(0.05)\end{array}$ \\
\hline Edge of grass & $\begin{array}{l}86.48 \\
(3.15)\end{array}$ & $\begin{array}{c}0.37 \\
(0.07)\end{array}$ & $\begin{array}{r}107.82 \\
(2.42)\end{array}$ & $\begin{array}{c}0.69 \\
(0.10)\end{array}$ & $\begin{array}{c}3.79 \\
(0.81)\end{array}$ & $\begin{array}{c}0.44 \\
(0.07)\end{array}$ \\
\hline Grass (quarter) & $\begin{array}{r}202.57 \\
(5.40)\end{array}$ & $\begin{array}{c}1.48 \\
(0.21)\end{array}$ & $\begin{array}{r}112.43 \\
(2.35)\end{array}$ & $\begin{array}{c}0.84 \\
(0.06)\end{array}$ & $\begin{array}{l}12.33 \\
(1.25)\end{array}$ & $\begin{array}{c}1.51 \\
(0.20)\end{array}$ \\
\hline Grass (center) & $\begin{array}{r}213.92) \\
(5.93)\end{array}$ & $\begin{array}{c}1.55 \\
(0.16)\end{array}$ & $\begin{array}{l}99.60 \\
(3.54)\end{array}$ & $\begin{array}{c}1.33 \\
(0.13)\end{array}$ & $\begin{array}{l}13.85 \\
\{1.41\}\end{array}$ & $\begin{array}{l}1.55 \\
(0.40)\end{array}$ \\
\hline
\end{tabular}




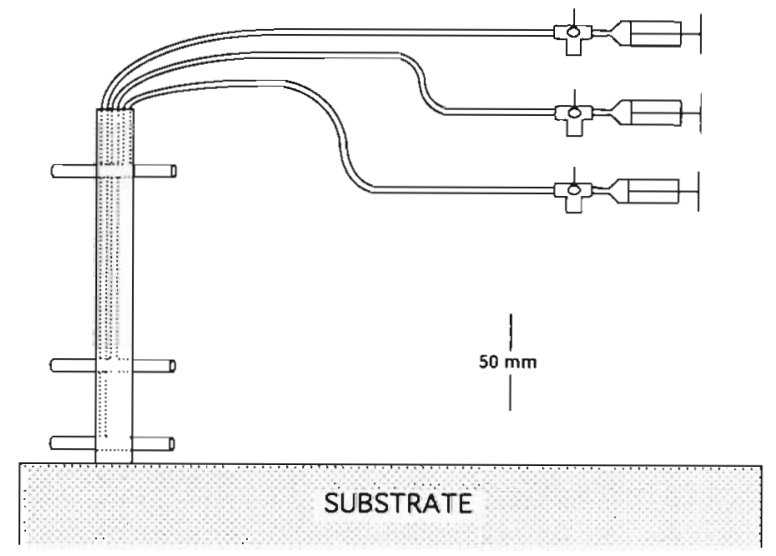

Fig. 2. Water sampling apparatus to mimic the active suspension-feeding bivalve, Mercenaria mercenaria. Simultaneous samples were collected manually via syringes at $1,5,15$, and, when water depth was sufficient, $45 \mathrm{~cm}$ above the bottom with an intake velocity of 1 to $2 \mathrm{~cm} \mathrm{~s}^{-1}$. Intake ports, $6.4 \mathrm{~mm}$ in diameter to simulate a $60 \mathrm{~mm} \mathrm{M}$. mercenaria, were held perpendicular to the flow direction and parallel to the bottom. The 3-way stopcock (proximal to the syringe) allowed for purging of the seawater rinse prior sample collection

Sampling of food resources. To distinguish the clam-biased food particle concentrations from those collected using traditional sampling techniques, we have chosen to use the term 'food resource' in this paper to indicate the chlorophyll concentration perceived by the clam. The clam-biased chlorophyll a abundance, as an indirect assay of the microalgal food resource (Jørgensen 1966), was determined fluorometrically (Parsons et al. 1984). Within each habitat (bare sand, edge of seagrass bed, or within a seagrass bed), water was sampled $1 \mathrm{~cm}$ above the bottom with 2 horizontal $6.4 \mathrm{~mm}$ intake tubes orthogonal to the current direction (Fig. 2). A suction velocity of ca 1 to $2 \mathrm{~cm} \mathrm{~s}^{-1}$ was used to match the incurrent siphon diameter and pumping rate of a $60 \mathrm{~mm}$ (length) hard clam (Walne 1972, Monismith et al. 1990). The $1 \mathrm{~cm}$ sampling height was chosen because laboratory observations of Mercenaria mercenaria suggested that siphons can be extended 5 to $10 \mathrm{~mm}$ above the bottom and, to a lesser extent, for experimental tractability. No adequate field observations of $M$. mercenaria siphon extension exist to corroborate this sampling height.

The choice of a constant pumping rate (at a given temperature) is valid from the few studies directly measuring pumping rate in flowing water (Hildreth 1976. Fiala-Médioni 1978). Pumping rate is not necessarily synonymous with filtration rate. Filtration rates measure the change in water column concentrations (not at the siphon) and assume the water is well-mixed, i.e. no concentration gradients exist adjacent to the suspension feeder (Coughlan 1969). Monismith et al.
(1990) have provided convincing evidence that siphonate bivalves, such as $M$. mercenaria, can re-filter some of their diluted exhalant filtrate. Therefore, concentration gradients often occur at the level of the siphon and cause filtration rates to underestimate pumping rates, especially in still water.

A vertical $1.9 \mathrm{~cm}$ diameter polyvinylchloride (PVC) pipe held the double intake tubes (separated by ca $6 \mathrm{~cm}$ ) at a fixed height above the bottom. Tygon ${ }^{\mathrm{TM}}$ tubing conveyed the water sample from the sampling port, up the inside of the PVC pipe and out to the position of the experimenter located at least $1 \mathrm{~m}$ downstream. The PVC pipe had a flat ( $2 \mathrm{~mm}$ thick) rectangular base $(1 \times 10 \mathrm{~cm})$ which prevented it from sinking into soft substrata; sufficient time ( 3 to $5 \mathrm{~min}$ ) was allowed after placement of the sampling apparatus to allow any disturbed sediment to resettle or move downstream. No further attempt was made to block the capture of seston aggregates (see later discussion of chlorophyll degradation products). For comparative purposes, separate simultaneous water samples were also collected similarly at 5,15 , and $45 \mathrm{~cm}$ above the bottom.

Immediately prior to collecting the samples, all intake tubes were rinsed with more than $30 \mathrm{ml}$ of unfiltered seawater (greater than 3 times the volume of the Tygon ${ }^{T M}$ tube) at the same pumping rate. A 3-way stopcock allowed for the discharge of the rinse and ensured that the water samples always flowed in 1 direction in the tube. Samples of approximately $50 \mathrm{ml}$ (over 75 to 90 s) were drawn manually by $60 \mathrm{cc}$ syringes and then passed through filter paper (Whatman GF/C, pore diameter $1.2 \mu \mathrm{m}$ ) having approximately the same retention efficiency as the bivalve ctenidia (Peterson \& Black 1991). The chlorophyll was extracted by placing the filter paper, while in the field, into $10 \mathrm{ml}$ of $90 \%$ acetone, vortexed, and placed on ice in the dark for $24 \mathrm{~h}$. The following day, the sample was centrifuged and a subsample was gently poured into a cuvette. Chlorophyll a measurements were read on a fluorometer (Turner Designs), before and after adding 2 drops of $1 \mathrm{~N} \mathrm{HCl}$ to identify phaeophytins (Parsons et al. 1984). Significant resuspension (caused by sampling or otherwise) can be verified through a phaeophytin to sampling height relationship, because chlorophyll degradation products are generally only common within sediments (Fréchette \& Bourget 1985). On one date (28 August 1990), water samples, collected at all heights in 2 habitats (bare sand and within seagrass bed) and fixed immediately with Lugol's solution, were analyzed directly for species composition.

Design of field experiments. Variability in food supply has been shown to be important to bivalve growth rates (Fréchette \& Bourget 1987); consequently, we conducted experiments on several scales for comparison. Data was collected bi-monthly for 1 yr and every 
$4 \mathrm{~h}$ over one $24 \mathrm{~h}$ period. Samples were taken in habitats similar to those used for several Mercenaria mercenaria growth experiments (Coen \& Heck 1991, Wilson 1991, Judge et al. 1992, Coen, Heck \& Judge unpubl.). In the bi-monthly program, vertical profiles were sampled at 4 horizontal locations (bare sand, edge of seagrass Halodule wrightii bed, and 2 distances into the seagrass bed) representing different habitat types. The habitat types were each separated by $12 \mathrm{~m}$. On each date, the sampling position was chosen haphazardly in each habitat. Two PVC pipe sampling apparati were placed $4.5 \mathrm{~m}$ apart and both depth profiles were taken simultaneously. A third chlorophyll depth sample was obtained 15 min later from 1 apparatus left in position. After sampling 1 habitat type, we moved to the next habitat (generally starting with the sand and progressing into the seagrass bed). The 3 chlorophyll samples collected from a given height and habitat were iredied as replicates on each date. This lumping of replicates is justified because the temporal replicate (separated by $15 \mathrm{~min}$ ) was not significantly different (ANOVA on transformed data, $F_{1,234}=$ $0.95, p=0.331$ ) from the 2 earlier simultaneous samples (separated by $4.5 \mathrm{~m}$ ) if dates are considered blocks. The entire sampling program across all habitats was completed by 2 researchers within $2 \mathrm{~h}$. A single patch of water could not be followed because currents at Perdido Pass do not move sequentially across each habitat type.

During the 24 h program (13 and 14 August 1991), samples were collected similarly except that only 1 location was used in the seagrass habitat (i.e. center). Two apparatuses (separated by $1 \mathrm{~m}$ ) were used in each habitat type ( 6 in total). Two replicate vertical profiles (separated by $1 \mathrm{~min}$ ) were collected simultaneously across all habitats. All samples at each sampling period were completed by 4 researchers within 5 min.
The PVC sampling apparatuses were left in place throughout the $24 \mathrm{~h}$ period.

Currents were also measured during this $24 \mathrm{~h}$ period with 3 Marsh-McBirney 511 electromagnetic current meters and 3 hot bead anemometers connected to voltmeters (LaBarbera \& Vogel 1976, as modified by $M$. Patterson pers. comm.). The hot bead anemometers were necessary in situations where the electromagnetic meters were not reliable (i.e. speeds less than 2 $\mathrm{cm} \mathrm{s}^{-1}$ or locations in highly sheared flow fields). In our study, the hot bead sensors were used for all but the near-surface measurements. At each chlorophyll sampling time, near-surface $(5$ to $10 \mathrm{~cm}$ below water-air interface) current speeds in the 3 habitats were estimated simultaneously from two $90 \mathrm{~s}$ measurements with the 3 electromagnetic current meters. On 3 occasions, speed-depth profiles were obtained by averaging 1 min of simultaneous measurememts for the 3 hot bead anemometers (located at 5, 1.5, and $25 \mathrm{~cm}$ above the bottom) and 1 electromagnetic current meter (located just below the surface). Velocity profiles were collected sequentially in the 3 different habitat types.

Data analysis. Chlorophyll a variability increased with mean concentration; consequently, data analysis was performed on the $\log _{10}$-transformed chlorophyll concentration. Food availability close to the bottom $(1 \mathrm{~cm})$ for both yearly and daily periods was analyzed by a 2 -way ANOVA for both habitat type and time. To evaluate the depth distribution of food particles within the water column, chlorophyll depth profiles were compared by a 2-way ANOVA (without replication for time) for height and habitat type. Phaeophytin percentages, for each date, were angular (arcsine) transformed $\left[\sin ^{-1}\left(\mathrm{p}^{1 / 2}\right)\right]$ to achieve normality prior to a 2-way ANOVA for height and habitat type. Near-surface current speeds during the 24 h period were compared by ANOVA for habitat type. When significant

Table 2. Food resource ANOVA for ( $\log _{10}$-transformed) chlorophyll a concentrations at $1 \mathrm{~cm}$ above bottom for 2 temporal scales

\begin{tabular}{|c|c|c|c|c|c|}
\hline Source & $d f$ & SS & MS & $F$ & $p$ \\
\hline \multicolumn{6}{|l|}{ Annual } \\
\hline Habitat (H) & 3 & 1.275 & 0.425 & 15.455 & $<0.001$ \\
\hline Date (D) & 5 & 1.340 & 0.268 & 9.748 & $<0.001$ \\
\hline $\mathrm{H} \times \mathrm{D}$ & 15 & 1.386 & 0.092 & 3.361 & 0.001 \\
\hline Error & 48 & 1.320 & 0.028 & & \\
\hline \multicolumn{6}{|l|}{ Multiple $r^{2}=0.752$} \\
\hline \multicolumn{6}{|l|}{ Daily } \\
\hline Habitat $(\mathrm{H})$ & 2 & 2.911 & 1.455 & 27.249 & $<0.001$ \\
\hline Time (T) & 5 & 1.035 & 0.207 & 3.876 & 0.015 \\
\hline $\mathrm{H} \times \mathrm{T}$ & 10 & 0.702 & 0.070 & 1.314 & 0.295 \\
\hline Error & 18 & 0.961 & 0.053 & & \\
\hline \multicolumn{6}{|l|}{ Multiple $r^{2}=0.829$} \\
\hline Edge & Grass & & & & \\
\hline
\end{tabular}


main effects were detected, a posteriori contrasts were performed (SYSTAT) to distinguish among treatment levels.

\section{RESULTS}

\section{Annual food resources}

Chlorophyll a concentrations of the water samples collected in a Mercenaria mercenaria-specific fashion are shown in Fig. 3A. Throughout the year, chlorophyll concentrations are generally greater within seagrass than the bare sand or edge habitats (mean of each date $\pm \mathrm{SE}$; Grass (center): $4.62 \pm 0.96 \mu \mathrm{gl}^{-1}$, Grass (quarter): $3.35 \pm 0.81$, Edge: $2.12 \pm 0.37$, Sand: $2.00 \pm 0.49$ ). However, a significant interaction between date and habitat type precludes identification of clear main effects (Table 2, Annual). Collapsing the 2 grass positions into a single grass treatment did not change the qualitative result.

If dates are considered blocks, then chlorophyll con-

\section{Annual Food Resources}

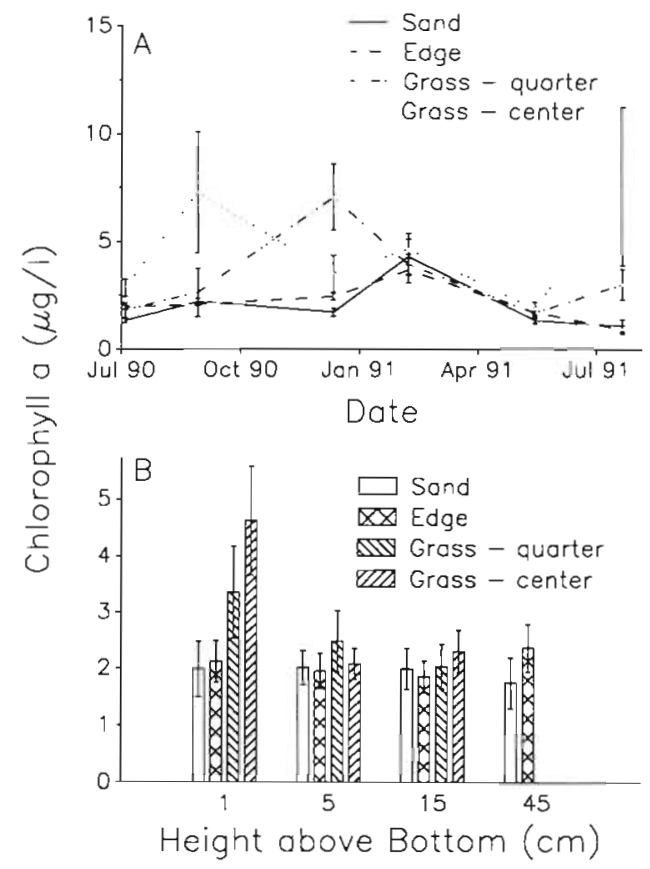

Fig. 3. (A) Food resources (mean $\pm 1 \mathrm{SE}, \mathrm{n}=3$ ) at $1 \mathrm{~cm}$ above the bottom throughout the year Chlorophyll a exhibited much variation between sites over time (ANOVA, Habitat $x$ Date, $F_{3,15}=3.361, \mathrm{p}=0.001$ ). (B) Histogram of mean chlorophyll concentration ( $\pm 1 \mathrm{SE}, \mathrm{n}=6$ ) at each height averaged throughout the year. Chlorophyll levels closest to the bottom were typically greater than the mean of all higher samples (ANOVA, $F_{1,66}=7.949, \mathrm{p}=0.006$ ). Samples drawn $5 \mathrm{~cm}$ and above did not vary with height (ANOVA, $F_{z, 46}=0.565$,

$$
\mathrm{p}=0.572 \text { ) }
$$

centrations across all habitats are independent of height for samples drawn between 5 and $45 \mathrm{~cm}$ above the bottom (ANOVA, $F_{2,46}=0.565, p=0.572$; Fig. 3B). Moreover, the mean chlorophyll concentration is higher adjacent to the bottom ( $1 \mathrm{~cm}$ sampling height) than the combined average of the 5,15 , and $45 \mathrm{~cm}$ sampling heights (ANOVA, $F_{1,66}=7.949, \mathrm{p}=0.006$; Fig. $3 \mathrm{~B})$. Although the baseline chlorophyll levels vary throughout the year, the vertical pattern was similar on most sampling dates. Further evidence that near-bottom waters represent a qualitatively different chlorophyll a regime comes from a comparison of the coefficient of variation by sampling height. Using all untransformed data, the seagrass habitats near the bottom (0.73) are nearly twice as variable in chlorophyll $a$ as the $5 \mathrm{~cm}$ sampling height $(0.47)$. The bare sand and edge habitats also exhibit increased variability adjacent to the bottom $(0.62$ and 0.44 , respectively, vs 0.43 and 0.41 ), but to a lesser extent. Moreover, although pennate benthic diatoms (primarily Licmophora spp. and Amphora spp.) generally are more common in all near bottom samples (Table 3), they

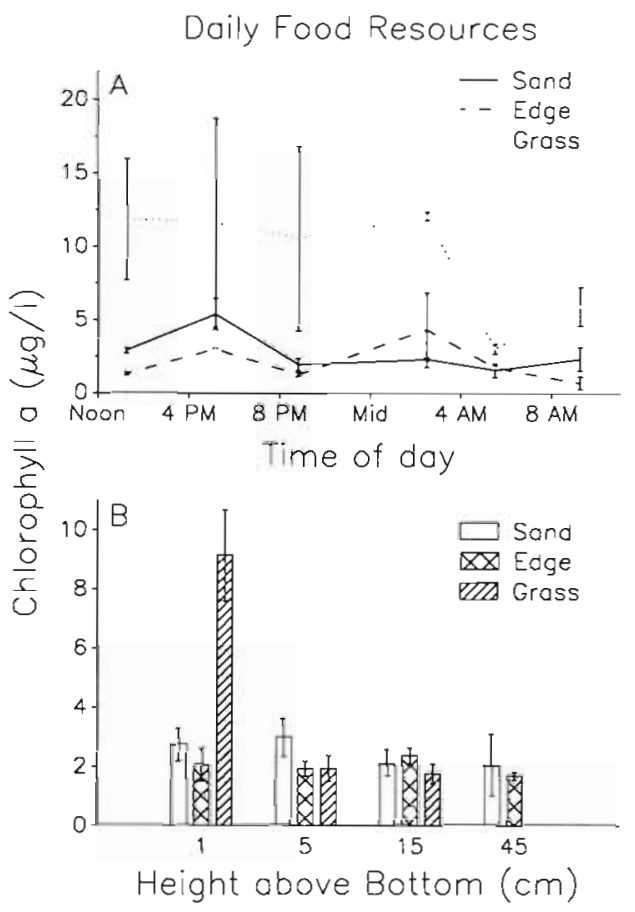

Fig. 4. (A) Food resources (mean $\pm 1 \mathrm{SE}, \mathrm{n}=2$ ) at $1 \mathrm{~cm}$ above the bottom during a $24 \mathrm{~h}$ period (13 \& 14 August 1991). Chlorophyll a varied significantly between sites (grass samples were higher than the other 2 habitats] and over time (Table 2B). (B) Histogram of mean chlorophyll concentration $( \pm 1 \mathrm{SE}, n=6$ ) at each height averaged throughout the day. Chlorophyll levels were greatest near the bottom in the seagrass bed (ANOVA, Height $\times$ Habitat, $F_{4,45}=7.912$, $p<0.001$ ), while samples drawn at $5 \mathrm{~cm}$ and $15 \mathrm{~cm}$ did not differ (ANOVA, $F_{1,30}=0.255, \mathrm{p}=0.617$ ) 
Table 3. Microalgal species list from water samples collected on 28 August 1990. Diatom species (count) are shown from the highest water column sampling height $(45 \mathrm{~cm})$ and adjacent to the bottom $(1 \mathrm{~cm})$ in both the bare sand and seagrass center habitat. A single dinoflagellate (Prorocentrum sp.) was also found in the water column sample

\begin{tabular}{|c|c|c|}
\hline Sampling position & Pennate & Centric \\
\hline $45 \mathrm{~cm}$ & $\begin{array}{l}\text { Hantzschia sp. (1) } \\
\text { Licmophora sp. (3) } \\
\text { Mastogloia sp. (1) } \\
\text { Navicula sp. (1) } \\
\text { Nitzschia closterium (3) } \\
\text { Nitzschia sp. (1) } \\
\text { Synedra sp. (1) }\end{array}$ & $\begin{array}{l}\text { Coscinodiscus sp. (2) } \\
\text { Centric species \#1 (1) } \\
\text { Centric species \#2 (1) } \\
\text { Centric species \#3 (1) }\end{array}$ \\
\hline $1 \mathrm{~cm}$, sand & $\begin{array}{l}\text { Amphora sp. (1) } \\
\text { Licmophora remulus (2) } \\
\text { Nitzschia angularis (1) } \\
\text { Nitzschia closterium (3) }\end{array}$ & $\begin{array}{l}\text { Actinoptychus senarius (1) } \\
\text { Rhizosolenia sp. (3) }\end{array}$ \\
\hline $1 \mathrm{~cm}$, grass & $\begin{array}{l}\text { Amphora proteus (1) } \\
\text { Amphora angusta (2) } \\
\text { Amphora sp. (1) } \\
\text { Grammatophora oceanica (2) } \\
\text { Gyrosigma sp. (1) } \\
\text { Licmophora remulus (9) } \\
\text { Licmophora sp. (4) } \\
\text { Mastogloia sp. (3) } \\
\text { Navicula sp. (2) } \\
\text { Nitzschia angularis (1) } \\
\text { Pleurosigma sp. (1) } \\
\text { Rhopalodia acuminata (4) } \\
\text { Synedra sp. (3) } \\
\text { Tropidoneis sp. (3) }\end{array}$ & $\begin{array}{l}\text { Cymatosira lorenziana (1) } \\
\text { Melosira sp. (3) }\end{array}$ \\
\hline
\end{tabular}

contribute up to $90 \%$ of the total algal cell count within the seagrass, but only $60 \%$ within the sand habitat. Typical planktonic diatoms (Skeletonema spp. and Chaetoceros spp.) were not found in any samples ( $M$. Sullivan pers. obs. for 28 August 1990). In contrast to the chlorophyll concentrations, phaeophytins within the water samples never varied significantly with height above the bottom (ANOVAs on each sampling date, all p's $>0.4$ ) suggesting that resuspension played only a minor role in this pattern and that our sampling did not suck sediments off the bottom.

\section{Daily food resources}

Chlorophyll a concentrations and variability applicable to an individual Mercenaria mercenaria on an hourly scale (Fig. 4A) were similar to the year-long pattern. Chlorophyll varied significantly with time and habitat with no significant interaction effect (Table 2 , Daily). Throughout the day, the seagrass habitat exhibited significantly ( $p<0.001$ ) greater chlorophyll levels $\left(9.15 \pm 1.54 \mu \mathrm{l}^{-1}\right.$, mean $\pm \mathrm{SE}$ ) than either the edge $(2.05 \pm 0.55)$ or bare sand $(2.73 \pm 0.56)$ habitats. As with the year-long results, if sampling times are considered blocks, then mean chlorophyll concentration is greater $1 \mathrm{~cm}$ above the bottom than at $5 \mathrm{~cm}$ or $15 \mathrm{~cm}$, but only significantly so for the seagrass habitats (Height $\times$ Habitat interaction, $F_{4,45}=7.912, \mathrm{p}<0.001$ ) . Re-analyzing without the $1 \mathrm{~cm}$ samples, chlorophyll concentrations at 5 and $15 \mathrm{~cm}$, averaged over the day, are indistinguishable (ANOVA, $F_{1,30}=0.255, \mathrm{p}=0.617$ ) across all habitats (Fig. 4B).

\section{Near Surface Current Speeds}

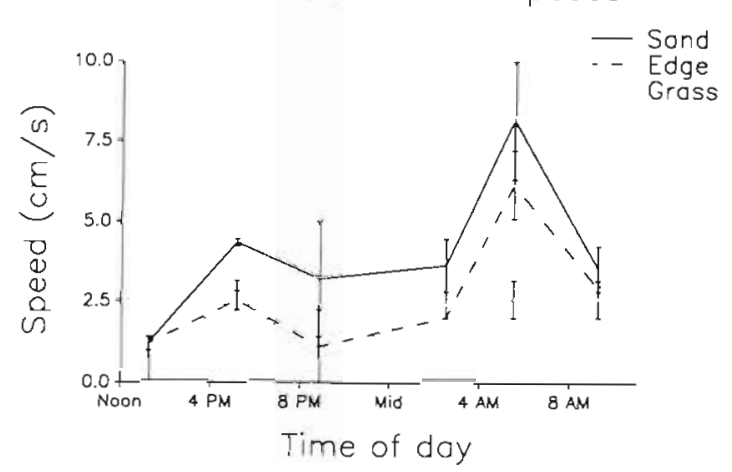

Fig. 5. Near surface current speed (mean $\pm 1 \mathrm{SE}$ for two $90 \mathrm{~s}$ sampling bouts) during a 24 h period (13 \& 14 August 1991). Speeds varied significantly between sites (ANOVA, $F_{2.18}=$ 9.67. $\mathrm{p}=0.001$ ) with speeds above the bare sand higher than the other 2 habitats and over time 


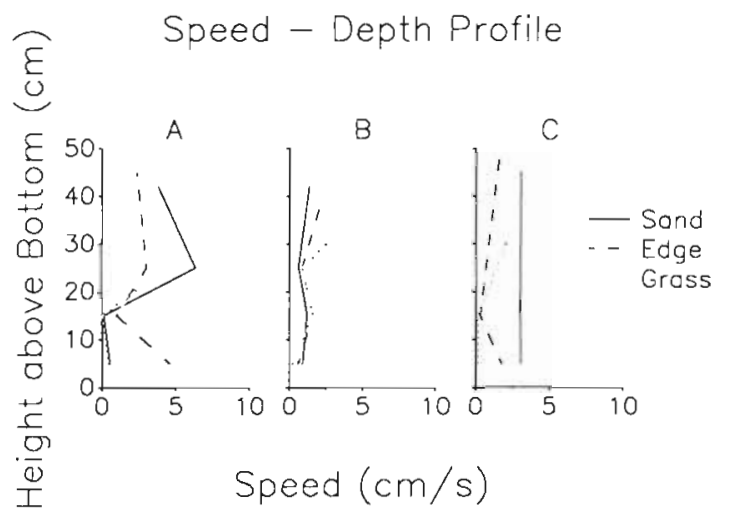

Fig. 6. Velocity depth profiles at 3 times during $24 \mathrm{~h}$ period at each of the 3 habitat types. (A) 17:00 h, 13 August 1991;

(B) 21:00 h, 13 August 1991; (C) 10:00 h, 14 August 1991

\section{Variability in water flow}

Near surface current speeds (averaged over $3 \mathrm{~min}$ ) during the $24 \mathrm{~h}$ sampling period are shown in Fig. 5. Current speeds 5 to $10 \mathrm{~cm}$ below the air-water interface varied from near $1 \mathrm{~cm} \mathrm{~s}^{-1}$ to greater than $8 \mathrm{~cm} \mathrm{~s}^{-1}$ and were significantly different among habitat types (ANOVA, $F_{2,18}=9.67, \mathrm{p}=0.001$ ), with measurements above the bare sand $\left(4.02 \mathrm{~cm} \mathrm{~s}^{-1}\right)$ consistently higher. Mean currents above the seagrass $\left(1.95 \mathrm{~cm} \mathrm{~s}^{-1}\right)$ and edge $\left(2.66 \mathrm{~cm} \mathrm{~s}^{-1}\right)$ were not significantly different (a posteriori contrast, $F_{1,18}=2.174, p=0.158$ ). Currents switched direction several times during the 24 h sampling period.

The velocity-depth profiles (Fig. 6) exhibited substantial variation during the $24 \mathrm{~h}$ sampling period. Sometimes, the velocity profiles varied unpredictably with height and habitat (Fig. 6A) or, during other periods, the water was slack (Fig. 6B). At other times, flow velocities were more consistent with a priori expectations (Peterson et al. 1984, Gambi et al. 1990) about flow near seagrass beds (i.e. uniformly higher above the sand habitats, Fig. 6C). However, even though the near surface currents at the edge of the grass bed appeared similar to the seagrass habitat, the bottom currents near the edge were always greater than those in the seagrass and, in fact, were more similar to the sand.

\section{DISCUSSION}

\section{Patterns of variability}

The uniformity of chlorophyll a measurements above the bare sand and grass edge during each sampling period suggests that food is well-mixed in these habitats. Although phytoplankton have often been ob- served to be vertically structured in deep water (Steele \& Yentsch 1960), mixing in many shallow estuarine environments is sufficient to eliminate stratification of chlorophyll (Holligan et al. 1984). Turbulence in these waters increases mixing and replenishes food resources at the bottom (Denny \& Shibata 1989, Fréchette et al. 1989). In Perdido Pass, the shallow sandy habitat probably has substantial vertical mixing relative to the removal by suspension feeders and deposition. Consequently, estimates of food resources are not likely dependent upon sampling height.

In contrast to the bare sand and edge habitats, food resources, as indicated by the clam-biased chlorophyll a concentrations, within the seagrass habitat are considerably greater just above the bottom than in the overlying water column. The mean food resources near the bottom even surpassed the annual maximum values observed at 5,15 , or $45 \mathrm{~cm}$ above the substrate. Although the coefficient of variation in mean food abundance in all habitats increases towards the bottom, the magnitude of this increase in the seagrass habitat is exceptionally large.

Based on the cell counts, much of the increase in chlorophyll a within the seagrass bed appears to have been generated locally (i.e. in the immediate vicinity of the clam) as benthic or epiphytic algal cells slough off or become resuspended, and not from the deposition of phytoplankton from the water column above (Peterson et al. 1984). If the deposition of phytoplanktonic diatoms had played a major role in Perdido Pass, then relatively more phytoplankton cells would have been expected in the near-bottom samples, rather than the observed higher relative abundance of benthic diatoms. Although the low current speeds measured in the seagrass habitat suggest little mixing at the bottom, we are unable to distinguish fully between greater microalgal growth and resuspension. However, in Perdido Pass, the lack of a significant relationship between the percentage of phaeophytins and sampling height above the bottom indicates that resuspension events (or sucking in sediments while sampling) are probably small relative to the benthic/epiphytic algal production as a clam food source. Taken together, these results suggest that active suspension feeders, like Mercenaria mercenaria, feeding just above the bottom within seagrass meadows experience a significantly different food source than those feeding in unvegetated areas. Feeding heights less than $1 \mathrm{~cm}$ above the bottom may produce even greater food resource estimates.

Substantially similar patterns were observed during our more intensive $24 \mathrm{~h}$ sampling period. Again, food resources increased markedly near the bottom in the seagrass habitat. Although continuous measurement of food resources is necessary to allow definitive con- 
clusions about the feeding environment, it is intriguing that both the yearly and $24 \mathrm{~h}$ patterns ( 2 periods common to growth studies) share many characteristics in the Perdido Pass study site

The generally higher current speeds (and degree of mixing) above the bare sand are consistent with the uniform chlorophyll a distribution in the sand habitat. Similarly, the low current speeds near the bottom in the seagrass bed (generally less than $1 \mathrm{~cm} \mathrm{~s}^{-1}$ ) support the development of vertical gradients of chlorophyll a and suggest that resuspension is unlikely in this habitat. While flow observations on a single day cannot characterize all flow conditions, the near bottom current patterns corroborate the food level patterns observed among these habitat types. In general, the near bottom within the seagrass beds with its very low current speeds seems to be a qualitatively different regime than the other habitats, as noted previously by Peterson et al. (1984) and Gambi et al. (1990).

Given the chlorophyll a vertical gradients and the presence of chain-forming benthic diatoms, models incorporating food resources to predict suspension feeder growth must pay careful attention to food and perhaps hydrodynamic regimes that the clam experiences at its incurrent siphon (see Butman 1989 for a review). For example, in our system, the absence of reduced food resources adjacent to the bottom would argue against significant resource depletion for an individual clam. Resource depletion could be a scale dependent phenomenon (Ertman \& Jumars 1988), however, and larger scale (e.g. population level) resource depletion may still be possible through the combined action of many filtering organisms (Fréchette \& Bourget 1985, Peterson \& Black 1987, Fréchette et al. 1989).

\section{Sampling food availability from the clam's perspective}

Two mechanistic reasons exist for sampling food resources from the clam's perspective (i.e. simulating pumping rate and incurrent tube size) rather than isokinetically (collection speed to match ambient velocity). First, isokinetic sampling collects particles at their instantaneous concentrations (Wildish \& Kristmanson 1984, Mushenheim et al. 1986) while the clam's pumping can bias food concentrations at the siphon by differentially collecting particles from suspension. Although phytoplankton cells, by virtue of their small size, will tend to follow streamlines, larger particles, such as chain-forming benthic diatoms (as seen here) or sediment aggregates, may not. If the paths of larger particles do not conform to changes in water direction at the inhalant siphon, they will be underrepre- sented in the collections. For example, intake speeds faster than ambient velocities can produce estimates $50 \%$ below the instantaneous concentrations in suspensions of sediments (Vanoni 1946) and resuspended sedimentary organic matter has been shown to be a source of food for suspension-feeding bivalves (Kiørboe et al. 1981, Bricelj \& Malouf 1984). Although inappropriate for active suspension feeders, isokinetic sampling may be realistic for passive suspension feeders.

Second, isokinetic sampling of chlorophyll $a$ at a fixed height will also provide misleading estimates of food resources when chlorophyll concentrations are vertically structured because the clam collects water from different regions of the water column with changing ambient current speeds. This latter problem is exacerbated at low flow conditions, such as those generally found near the benthos (especially within a seagrass canopy as shown herel. At high flows, this problem is reduced (i.e. the clam 'feeding zone' converges on the sampling height) but the former problem (biased sampling) gains in importance.

The pertinence of our study would be further demonstrated if we had conducted a simultaneous isokinetic sampling program with the same incurrent siphon diameter $(6.4 \mathrm{~mm})$ for comparison. Unfortunately, because Perdido Pass had low chlorophyll levels (accurate measurements necessitate at least $30 \mathrm{ml}$ water samples), a sampling pipe almost $1 \mathrm{~m}$ in length would have been required. Pumps, combined with feedback of ambient flow conditions at each incurrent tube opening, would have been needed to overcome the flow resistance in these narrow pipes. Consequently, matching incurrent speeds to field flow conditions at several heights simultaneously was not feasible. Thus, although we cannot address the absolute importance of sampling rate and tube diameter, we have nonetheless shown the consequence of using relevant sampling heights in vertically stratified food environments.

In conclusion, we recommend that future models of active benthic suspension feeder growth measure food resources at a height applicable to the study organism and employ sampling protocols with realistic pumping rates and incurrent tube diameters (e.g. Grizzle et al. 1992). By species-specific changes in parameter values, our protocol could be easily adapted to other active benthic suspension feeders. Moreover, from the expermenter's point of view, our protocol is easy to implement and has the advantage over traditional methods in that potential biases from unknown. food particle buoyancies and non-uniform vertical distributions are reduced. Finally, this protocol could be improved in future studies by incorporating variation in food quality and potential behavioral modifications of pumping rate 
to yield more mechanistically realistic predictors of benthic suspension feeder growth.

Acknowledgements. The authors are indebted to J. Nelson, $M$. Doster, and L. Hartman for their help in the field. We also thank J Pennock for assistance with the sampling protocol. R. Zimmer-Faust lent us the electromagnetic current meters and $M$. Patterson donated his design schematic and expertise to build the hot bead anemometers to measure water currents. $M$. Sullivan provided the taxonomic identification of diatoms from the water samples. This manuscript benefited from comments by $M$. Bricelj, F. Borrero, C. A. Butman, R. Grizzle, J. Levinton, C. H. Peterson, and 2 anonymous reviewers. M. Bricelj pointed out the utility of using phaeophytins as an index of resuspension level. This work was supported by NOAA's MARFIN, Department of Commerce, grant \#NA90AAHMF101 awarded to K. L. H. and L. D. C. and NSF equipment grant \#EAR-8912110 to J. Pennock, R. ZimmerFaust, and $\mathrm{J}$ Stout. To all we are grateful. This is Marine Environmental Sciences Consortium Contribution No. 208.

\section{LITERATURE CITED}

Bricelj, V. M., Malouf, R. E. (1984). Influence of algal and suspended sediment concentrations on the feeding physiology of the hard clam Mercenaria mercenaria. Mar. Biol. 84: $155-165$

Buss, L. W., Jackson, J. B. C. (1981). Planktonic food availability and suspension-feeder abundance: evidence of in situ depletion. J. exp. mar. Biol. Ecol. 49: 151-161

Butman, C. A. (1989). Sediment-trap experiments on the importance of hydrodynamical processes in distributing setthing invertebrate larvae in near-bottom waters. J. exp. mar. Biol. Ecol. 134: 37-88

Coen, L. D., Heck, K. L. Jr (1991). The interacting effects of siphon nipping and habitat on bivalve (Mercenaria mercenaria (L.)) growth in a subtropical seagrass (Halodule wrightii Aschers) meadow. J. exp. mar. Biol. Ecol. 145: $1-13$

Coughlan, J. (1969). The estimation of filtering rate from the clearance of suspensions. Mar. Biol. 2: 356-358

Denny, M. W., Shibata, M. F. (1989). Consequences of surfzone turbulence for settlement and external fertilization. Am. Nat. 134: 859-889

Ertman, S. C., Jumars, P. A. (1988). Effects of siphonal currents on the settlement of inert particles and larvae. J. mar. Res. 46: 797-813

Fegley, S. R., MacDonald, B. A., Jacobson, T. R. (1992). Shortterm variation in the quantity and quality of seston available to benthic suspension feeders. Estuar coast. Shelf Sci. 34: 393-412

Fiala-Médioni, A. (1978). Filter-feeding ethology of benthic invertebrates (Ascidians). III. Recording of water current in situ rate and rhythm of pumping. Mar. Biol. 45: 185-190

Frechette, M., Bourget, E. (1985). Energy flow between the pelagic and benthic zones: factors controlling particulate organic matter available to an intertidal mussel bed Can. J. Fish. Aquat. Sci. 42: 1158-1165

Fréchette, M., Bourget, E. (1987). Significance of small-scale spatio-temporal heterogeneity in phytoplankton abundance for energy flow in Mytilus edulis. Mar Biol. 94 $231-240$

Fréchette, M., Butman, C. A., Geyer, W. R. (1989). The impor- tance of boundary-layer flow in supplying phytoplankton to the benthic suspension feeder, Mytilus edulis L. Limnol. Oceanogr. 34: 19-36

Gambi, M. C., Nowell, A. R. M., Jumars, P. A. (1990). Flume observations on flow dynamics in Zostera marina (eelgrass) beds. Mar. Ecol. Prog. Ser. 61. 159-169

Grizzle, R. E., Langan, R., Howell, W. H. (1992). Growth responses of suspension-feeding bivalve molluscs to changes in water flow: differences between siphonate and nonsiphonate taxa. J. exp. mar. Biol. Ecol. 162: 213-228

Grizzle, R. E., Lutz, R. A. (1989). A statistical model relating seston fluxes and bottom sediment characteristics to growth of Mercenaria mercenaria. Mar. Biol. 102: 85-105

Holligan, P. M., Harris, R. P., Newell, R. C., Harbour, D. S., Head, R. N., Linley, E. A. S., Lucas, M. I., Tranter, P. R. G., Weekley, C. M. (1984). Vertical distribution and partitioning of organic carbon in mixed, frontal and stratified waters of the English channel. Mar. Ecol. Prog. Ser 14: 111-127

Hildreth, D. I. (1976). The influence of water flow rate on pumping rate in Mytilus edulis using a refined direct measurement apparatus. J mar. biol. Ass. U.K. 56: $311-319$

Irlandi, E. A., Peterson, C. H. (1991). Modification of animal habitat by large plants: mechanisms by which seagrasses influence clam growth. Oecologia 87: 307-318

Jørgensen, C. B. (1966). Biology of suspension feeding. Pergamon Press, Oxford

Jørgensen, C. B., Famme, P., Kristensen, H. S., Larsen, P. S., Møhlenberg, F., Riisgârd, H. U. (1986). The bivalve pump. Mar. Ecol. Prog. Ser. 34: 69-77

Judge, M. L., Coen, L. D., Heck, K. L. Jr (1992). The effect of long-term alteration of in situ water currents on the growth of Mercenaria mercenaria in the northern Gulf of Mexico. Limnol. Oceanogr. 37: 1550-1559

Kiorboe, T., Mohlenberg, F., Norh, O. (1981). Effect of suspended bottom material on growth and energetics in Mytilus edilus. Mar. Biol. 61: 283-288

LaBarbera, M. Vogel, S. (1976). An inexpensive thermistor flowmeter for aquatic biology. Limnol. Oceanogr. 21: $750-756$

Mitchell, J. G., Fuhrman, J. A. (1989). Centimeter scale vertical heterogeneity in bacteria and chlorophyll a. Mar. Ecol. Prog. Ser. 54: 141-148

Monismith, S. G., Koseff, J. R., Thompson, J. K., O'Riordan, C. A., Nepf, H. N. (1990). A study of model bivalve siphonal currents. Limnol. Oceanogr. 35: 680-696

Muschenheim, D. K., Grant, J., Mills, E. L. (1986). Flumes for benthic ecologists. Mar. Ecol. Prog. Ser. 28: 185-196

Parsons, T R., Takahashi, M., Hargrave, B. (1977). Biological oceanographic processes, 2nd edn. Pergamon, Oxford

Parsons, T R., Maita, Y., Lalli, C. M. (1984). A manual of chemical and biological methods for seawater analysis. Pergamon, Oxford

Peterson, C. H., Black, R. (1987). Resource depletion by active suspension feeders on tidal flats: influence of local density and tidal elevation. Limnol. Oceanogr. 32: 143-166

Peterson, C. H., Black, R. (1991). Preliminary evidence for progressive sestonic food depletion in incoming tide over a broad tidal sand flat. Estuar. coast. Shelf Sci. 32: 405-413

Peterson, C. H., Summerson, H. C., Duncan, P. B. (1984). The influence of seagrass cover on population structure and individual growth rate of a suspension-feeding bivalve. J. mar. Res. 42: 123-138

Steele, J. H., Yentsch, C. S. (1960). The vertical distribution of chlorophyll. J. mar. biol. Ass. U.K. 39: 217-226 
Vanoni, V. A. (1946). Transportation of sediment in suspension. Trans. Am. Soc. civil Eng. 111: 67-133

Walne, P. R. (1972). The influence of current speed, body size and temperature on the filtration rate of five species of bivalves. J. mar. biol. Ass. U.K. 52: 345-374

Wildish, D. J., Kristmanson, D. D. (1984). Importance to mus-

This article was presented by C. H. Peterson, Morehead City, N. Carolina, USA sels of the benthic boundary layer. Can. J. Fish. Aquat. Sci. 41. $1618-1625$

Wilson, D. M. (1991). The effect of submerged vegetation on the growth and incidence of siphon nipping of the northern quahog, Mercenaria mercenaria (Bivalvia). M.S. thesis, Univ of Alabama, Tuscaloosa

Manuscript first received: March 20, 1992

Revised version accepted: November 13,1992 